\title{
Influence of salinity on growth and cell volume in three strains of Prorocentrum cordatum (Dinophyceae)
}

\author{
Marina Monti-Birkenmeier ${ }^{1, *}$, Maja Berden Zrimec ${ }^{2}$, Luka Drinovec ${ }^{3}$, Alfred Beran ${ }^{1}$, \\ Alexis Zrimec ${ }^{4}$, Bruno Cataletto ${ }^{1}$, Serena Fonda Umani ${ }^{5}$ \\ ${ }^{1}$ Istituto Nazionale di Oceanografia e di Geofisica Sperimentale (OGS), 34151 Trieste, Italy \\ ${ }^{2} A l g E n, 1231$ Ljubljana, Slovenia \\ ${ }^{3}$ Research and Development Department, Aerosol, 1000 Ljubljana, Slovenia and Condensed Matter Physics Department, \\ Jožef Stefan Institute, 1000 Ljubljana, Slovenia \\ ${ }^{4}$ Abelium, 1000 Ljubljana, Slovenia \\ ${ }^{5}$ Department of Life Science, University of Trieste, 34127 Trieste, Italy
}

\begin{abstract}
The aim of this work was to test whether salinity is the driving factor for size and physiological differences in the dinoflagellate Prorocentrum cordatum. Three strains, isolated from 3 sites with different salinities (the central Baltic Sea, Sweden, salinity 8; Chesapeake Bay, Maryland, USA, salinity 16; and the Gulf of Trieste, northern Adriatic Sea, Italy, salinity 32), were included in this study. Following their molecular and morphological characterisation, specific growth rates and dimensions were examined for each strain cultivated at all 3 salinities (i.e. 8,16 and 32). The Adriatic strain always showed the largest cells and the Baltic strain the smallest. Adriatic and American strains showed lower specific growth rates at salinity 8 and highest at salinity 16 . The Baltic strain growth rates were similar at all salinities. As salinity 16 proved to be optimal for the strains, additional parameters were further compared at this salinity: cell volume, particulate organic carbon, particulate nitrogen, delayed fluorescence and in vivo chl a fluorescence. The Adriatic strain had the highest particulate organic carbon, particulate nitrogen, and delayed and in vivo fluorescence. Conversely, the Baltic strain had the lowest values. Although the strains had different specific growth rates with respect to salinity, this was not the main driving factor for the different sizes and photosynthetic activity among the strains. Thus, although there was low genetic variability among strains from the 3 geographical areas, intraspecific variability was suggested.
\end{abstract}

KEY WORDS: Prorocentrum cordatum $\cdot$ Salinity $\cdot$ Delayed fluorescence $\cdot$ Growth rate

\section{INTRODUCTION}

Dinoflagellates are the causative agents of harmful algal blooms; thus, they have been studied intensively in recent decades. Control of bloom events requires good knowledge of their basic features, including the adaptive strategies of the dinoflagellate species responsible, and an understanding of the environmental factors that regulate these events (Salgado et al. 2015).

\footnotetext{
${ }^{*}$ Corresponding author: mmonti@inogs.it
}

Prorocentrum cordatum (Ostenfeld) J. D. Dodge, 1975 (formerly Prorocentrum minimum [Pavillard] Schiller, 1933, and Exuviaella marie-lebouriae Parke \& Ballantine, 1957) (Velikova \& Larsen 1999, Taylor et al. 2003, Krakhmalny et al. 2004, Caroppo et al. 2017, Guiry \& Guiry 2017, Hoppenrath 2017) is a cosmopolitan dinoflagellate that lives in many coastal and brackish waters (Heil et al. 2005). This species can form harmful blooms (Silva 1980, Rabbani et al.

() The authors 2019. Open Access under Creative Commons by Attribution Licence. Use, distribution and reproduction are unrestricted. Authors and original publication must be credited. 
1990, Tseng et al. 1993, Moncheva et al. 1995, Grzebyk et al. 1997, Azanza et al. 2005) and can be toxic to humans through accumulation of its toxins in edible shellfish (Silva \& Sousa 1981, Silva 1985). P. cordatum shows wide variability of cell shape (i.e. ovate, triangular, heart shaped) and size (i.e. length 14$22 \mu \mathrm{m}$, width 10-15 $\mu \mathrm{m}$ ) (Dodge 1975). This high morphological variety has often led to the description of local forms of $P$. cordatum as new species (Martin 1929, Parke \& Ballantine 1957, Bursa 1959, Fukuyo et al. 1990, Marasović et al. 1990, Witek \& Pliński 2000), and thus a variety of synonyms can be found in the literature. Different studies have highlighted that the high variability in cell size of dinoflagellates might be a consequence of environmental factors including salinity, temperature, nutrients and light intensity (Solum 1962, Taylor et al. 1995, Velikova \& Larsen 1999, Hajdu et al. 2000, Pertola et al. 2003, Monti et al. 2005, Vanucci et al. 2012). Indeed, changes in salinity are known to affect morphological and physiological features of dinoflagellates (Jensen \& Moestrup 1997, Berden-Zrimec et al. 2008a, Laabir et al. 2011, Röder et al. 2012). However, little is known about the effects of salinity on $P$. cordatum.

In regard to growth, Hajdu et al. (2000) reported that Baltic clones of $P$. cordatum can grow at salinities between 2 and 35, with their optimal growth at 15 to 17 . Natural blooms of $P$. cordatum have been correlated with declining salinities (Mendez 1993), which have usually been associated with freshwater input and increased nutrient loading (Grzebyk \& Berland 1996, Glibert et al. 2001, Fan et al. 2003). Grzebyk \& Berland (1996) showed that Mediterranean strains of $P$. cordatum grow optimally at salinities between 15 and 35 and temperatures between 18 and $26.5^{\circ} \mathrm{C}$. Using a global modelling approach, Glibert et al. (2014) predicted the potential effects of nutrient loading and climate change for Prorocentrum. They calculated an expansion along the NW European Shelf-Baltic Sea region, with economic consequences and risk to human health and the ecosystem. Changes in temperature and salinity of the world's waters could also lead to modifications of algal blooms and the planktonic compartment (Wasmund et al. 2008).

The 3 strains used in the present study were previously isolated from 3 different areas: the central Baltic Sea (Sweden), Chesapeake Bay (Maryland, USA) and the Gulf of Trieste (northern Adriatic Sea, Italy). The respective salinities for their collection points were 8, 16 and 32. In the Baltic Sea, the first recorded bloom of P. cordatum was in 1979 (Tangen 1980), and since then, it is an annual component of the late sum- mer or autumn phytoplankton assemblage, where it can occasionally even be dominant (HELCOM 1996, Hajdu et al. 2000). P. cordatum blooms recur most years in the Chesapeake Bay mesohaline region in the late spring and summer, after its lengthy subpycnocline transport in the estuarine circulation (Tyler \& Seliger 1978, 1981, Harding \& Coats 1988). In the northern Adriatic Sea, P. cordatum was first recorded during the summer of 1983. It constituted a considerable portion of the regular summer bloom that occurred in the warm, low salinity water in the eastern Adriatic coast (Marasović 1986). Since then, the contributions of $P$. cordatum to summer blooms have continued to increase and the species has also been reported from other locations along the Adriatic coast (Fonda Umani 1985, Pucher-Petković \& Marasović 1987, Marasović et al. 1988, 1990, Marasović 1989, Cabrini et al. 2012).

The main aim of the present study was to test the hypothesis that salinity is one of the driving factors in the induction of size and physiological differences in different strains of the dinoflagellate $P$. cordatum. As the first step, molecular characterisation and morphological analyses of the 3 strains were carried out. Second, cell dimensions and specific growth rates were analysed for the 3 strains, with each cultured at 3 salinities (i.e. 8, 16, 32). At salinity 16, all the strains showed optimal growth, and this salinity was used to further investigate the strain differences in cell volume, particulate organic carbon (POC), particulate nitrogen (PN) and photosynthetic activity (i.e. delayed fluorescence [DF], in vivo fluorescence).

\section{MATERIALS AND METHODS}

\subsection{Algal cultures}

The Baltic strain of Prorocentrum cordatum (BAL) was collected in the central Baltic Sea and isolated at the Kristineberg Marine Research Station, Sweden. The American Chesapeake strain (D5) was obtained from D. Stoecker and was originally isolated from Chesapeake Bay, USA. The Adriatic strain (PmK) was isolated from the Gulf of Trieste, Italy, in the Adriatic Sea.

The non-axenic stock cultures were maintained at the National Institute for Experimental Geophysics and Oceanography (Istituto Nazionale di Oceanografia e di Geofisica Sperimentale), Trieste, Italy. They were kept at $15 \pm 0.5^{\circ} \mathrm{C}$, under cool-white fluorescent light (14 h light:10 h dark cycle, mean photosynthetically active radiation [PAR] $50 \pm 2 \mu \mathrm{mol} \mathrm{m}{ }^{-2} \mathrm{~s}^{-1}$ ) in 
f/2-Si medium (Guillard 1975), and at their original salinities (8 for BAL, 16 for D5 and 32 for PmK).

\subsection{Experimental culture conditions}

A week before the experiments, the strains were transferred to media with the new salinities (i.e. 8, 16, 32) for acclimation. The experimental cultures were inoculated to the initial cell concentration of about 1500 cells ml $\mathrm{m}^{-1}$ in $500 \mathrm{ml}$ Erlenmeyer flasks containing $350 \mathrm{ml}$ of the required medium. Three parallel cultures were grown for each strain at each salinity at $19.8 \pm 0.7^{\circ} \mathrm{C}$, under cool-white fluorescent light $(12 \mathrm{~h}$ light:12 h dark cycle, mean PAR $57 \pm 2 \mu \mathrm{mol} \mathrm{m}{ }^{-2} \mathrm{~s}^{-1}$ ). The locations of individual culture flasks within the growth chamber were randomly changed several times during the experiment.

\subsection{Molecular characterisation}

For each of the strains, genomic DNA was extracted from $50 \mathrm{ml}$ of exponentially growing cultures using the DNeasy ${ }^{\mathrm{TM}}$ Plant MiniKit (Qiagen), following the manufacturer's instructions. A portion of the subunit 18S rRNA gene was amplified using 1F (5'-AAC CTG GTT GAT CCT GCC AGT-3') and 1528R (5' -TGA TCC TTC TGC AGG TTC ACC TAC-3') primers (Montresor et al. 2004).

PCR amplification was performed as follows: initial denaturation of $94^{\circ} \mathrm{C}$ for $4 \mathrm{~min}$ followed by 30 cycles of $94^{\circ} \mathrm{C}$ for $2 \mathrm{~min}$ (denaturation), $56^{\circ} \mathrm{C}$ for $2 \mathrm{~min}$ (annealing) and $72^{\circ} \mathrm{C}$ for $2 \mathrm{~min}$ (extension). For each amplification, the following reaction mixture was used: $1 \mu \mathrm{l}$ of the template, $5 \mu \mathrm{l}$ of 10X HotMaster Taq Buffer with $\mathrm{Mg}^{2+}$ (Eppendorf), $5 \mu \mathrm{l}$ of each primer $(10 \mu \mathrm{M})$ (Sigma-Genosys), $1 \mu$ of deoxynucleosidetriphosphates $(10 \mu \mathrm{M}), 0.41$ of HotMaster Taq Polymerase (Eppendorf) and water to a final volume of $50 \mu \mathrm{l}$.

The PCR products were visualised on $0.8 \%(\mathrm{w} / \mathrm{v})$ agarose gels and stained with ethidium bromide $\left(0.5 \mu \mathrm{g} \mathrm{ml}^{-1}\right)$, and we used the DirectLoad ${ }^{\mathrm{TM}}$ Step Ladder (Sigma-Genosys) molecular weight marker to confirm amplification of the DNA fragments (1500 bp).

PCR products were purified using the UltraClean ${ }^{\mathrm{TM}}$ PCR Clean-up Kit (MoBio) according to the manufacturer's instructions.

18S rRNA gene nucleotide sequences were determined using ABI Prism ${ }^{\circledR}$ Big Dye ${ }^{\mathrm{TM}}$ (Applied Biosystems) dye terminator chemistry (Applied Biosystems) and an automated ABI Prism ${ }^{\circledR} 3700$ Genetic Analyzer (Applied Biosystems). The sequences were compared to known sequences in the GenBank database using BLAST (Altschul et al. 1997).

Phylogenetic analyses were performed on the Phylogeny.fr platform and comprised the following steps: the sequences were aligned with MUSCLE (v3.7) configured for highest accuracy, and after alignment, ambiguous regions were removed with Gblocks (v0.91b). The phylogenetic tree was reconstructed using the maximum likelihood method implemented in the PhyML program (v3.0). Graphical representation and editing of the phylogenetic tree were performed with TreeDyn (v198.3).

The sequences obtained in this study were deposited in GenBank under accession numbers MH976698, MH976699 and MH976700.

\subsection{Cell morphology}

Cell shape was examined at the original salinity. For scanning electron microscope (SEM) analyses, cells were fixed with $4 \%$ formaldehyde and stored at $4^{\circ} \mathrm{C}$ for $2 \mathrm{~d}$. The cells were then washed in a small amount of distilled water and dehydrated in an ascending series of ethyl alcohol $(30,50,80,95$, and $100 \%)$. The supernatant was removed each time after sedimentation of the cells (about $3 \mathrm{~h}$ ). Samples were $\mathrm{CO}_{2}$ critical point dried, coated with $\mathrm{Au} / \mathrm{Pd}$ and examined on a Leica-Cambridge Stereoscan 420i electron microscope.

\subsection{Cell dimensions and growth}

Cell dimensions and specific growth rate were analysed after shifting the 3 strains to each of the 3 salinities of 8, 16 and 32. Cell lengths and widths were measured at Days 3, 5, 7 and 10, during the exponential phase, under an inverted microscope (Leitz Labovert) at $320 \times$ magnification. At least 40 cells were examined for each strain and salinity.

To determine the cell numbers for the specific growth rate measures, aliquots of the cultures were collected every 2 to $3 \mathrm{~d}$ and preserved in $2 \%$ formaldehyde (final concentration). These were then examined under an inverted microscope (Leitz Labovert) at 320× magnification (Utermöhl 1958). The growth rates were calculated as the slope of the linear regression line of ln cell number $C$ for the time from the beginning $(t 1)$ to the end of the exponential growth phase $(t 2)$. The exponential growth rates $(\mu$, $\mathrm{d}^{-1}$ ) were calculated according to the equation $\mu=$ $(\ln C 2-\ln C 1) /(t 2-t 1)$. 


\subsection{Cell volume and elemental analysis}

At the intermediate salinity (16), the samples were also processed using an electronic particle counter (Coulter Multisizer, $100 \mu \mathrm{m}$ orifice tube, dimensional range $2-40 \mu \mathrm{m}$ ) for dinoflagellate volume and growth estimation.

Each sample was analysed twice as a 1:20 dilution to keep the coincidence error under $10 \%$. The curves obtained by the particle counter were processed using Acucomp software.

For the POC and PN analyses, the glassware and $\mathrm{GF} / \mathrm{F}$ filters used were precombusted for $4 \mathrm{~h}$ at $480^{\circ} \mathrm{C}$. The cells were harvested and filtered onto $25 \mathrm{~mm}$ GF/F filters on Days 3, 7, 11, 16, 20 and 27 for BAL and on Days 3, 7, 11, 15, 19, 24 and 28 for D5 and PmK. The filters were placed in aluminium foil sleeves, dried for $1 \mathrm{~h}$ at $60^{\circ} \mathrm{C}$ and stored at $-20^{\circ} \mathrm{C}$ until further analysis. The inorganic carbon was removed with $1 \mathrm{~N} \mathrm{HCl}$ (Hedges \& Stern 1984). All of the samples were run in triplicate. Blanks to correct for the contributions of the filter and the media to the background were prepared at the same time. POC and $\mathrm{PN}$ were measured using an elemental analyser (2400 CHNS/O, Perkin Elmer), with acetanilide used for the calibration curve.

\subsection{Delayed fluorescence and in vivo fluorescence}

At the intermediate salinity (16), DF and in vivo fluorescence were measured every 2 to $3 \mathrm{~d}$. Both measurements can be utilized for monitoring physiology and acclimated growth of microalgae (MacIntyre \& Cullen 2005, Wood et al. 2005, Zrimec et al. 2005).

In vivo chl a fluorescence (maximum fluorescence, Fm) was measured with the modulated chlorophyll fluorometer (PAM OS5-FL, OptiSciences). Maximum fluorescence is a fluorescence yield that is equal to the value which would be reached without any photochemical quenching (during a short intensive flash of light) (Maxwell \& Johnson 2000). The measurements were performed from the bottom of cuvettes containing $2 \mathrm{ml}$ samples of algal culture. The fluorescence was measured after $5 \mathrm{~s}$ of $50 \mu \mathrm{mol} \mathrm{m} \mathrm{m}^{-2} \mathrm{~s}^{-1}$ actinic illumination of the samples, without dark adaptation. Modulation intensity and gain were set to 255 .

DF was measured in a custom-made photon-counting luminometer (Monti et al. 2005, Berden-Zrimec et al. 2007, 2008b) containing a red light-sensitive photomultiplier tube (Hamamatsu R1104, Hamamatsu Photonics) with a photon counting unit (Hamamatsu C3866, Hamamatsu Photonics) for signal condition- ing and amplification. The instrument was coupled to a personal computer for data collection and elaboration (Monti et al. 2005, Berden-Zrimec et al. 2007, $2008 \mathrm{~b})$. The samples were measured in $6 \mathrm{ml}$ round cuvettes that were placed into a thermostated sample holder. Illumination was performed by a $20 \mathrm{~W}$ halogen lamp and wavelengths determined by filters.

DF was measured after 10 min of dark adaptation. Two light filters were used: a short-pass filter $(\lambda<$ $600 \mathrm{~nm}$ ) that provided a light intensity of $22 \mu \mathrm{mol} \mathrm{m}{ }^{-2}$ $\mathrm{s}^{-1}$ PAR at the sample position and a long-pass filter $(\lambda>650 \mathrm{~nm})$ that provided a light intensity of $12 \mu \mathrm{mol}$ $\mathrm{m}^{-2} \mathrm{~s}^{-1} \mathrm{PAR}$ at the sample position. The sample holder was temperature controlled to $20 \pm 0.1^{\circ} \mathrm{C}$. For each measurement, $2 \mathrm{ml}$ samples were illuminated for $3 \mathrm{~s}$ to subsequently measure the DF decay curves over the interval 1 to $60 \mathrm{~s}$ after the illumination pulse with a $0.1 \mathrm{~s}$ integration time. The background noise (i.e. dark current) was measured prior to each DF measurement and was then subtracted from the DF values.

Delayed fluorescence intensity (DFI) was calculated as the sum of the measured photon counts at a time interval of 1.1 to $2.1 \mathrm{~s}$ after sample illumination.

DF decay kinetics was evaluated by the peak intensity and position, i.e. the DF decay curves measured at the 2 illuminations were subtracted, and the resulting peak was evaluated for its intensity and position (Berden-Zrimec et al. 2008a,b).

\subsection{Statistical analyses}

Growth curves were compared using paired $t$-tests (paired ANOVA, p < 0.05). Cell dimensions (i.e. length, width) were analysed using Shapiro-Wilks and Bartlett's tests, which checked for normality and homoscedasticity of the data. As these conditions were not satisfied, non-parametric Friedman tests (2way ANOVA by ranks) for either length or width were applied to determine significant differences $(\mathrm{p}<0.05)$. Statistical analyses were performed using R-CRAN 2.4.1 software.

\section{RESULTS}

\subsection{Molecular characterisation}

The sequences of $18 \mathrm{~S}$ rRNA genes indicated that all 3 of these organisms were affiliated to the species Prorocentrum cordatum, with low genetic variability among these strains from the 3 geographical areas (i.e. Baltic Sea, Adriatic Sea, Chesapeake Bay). In the 


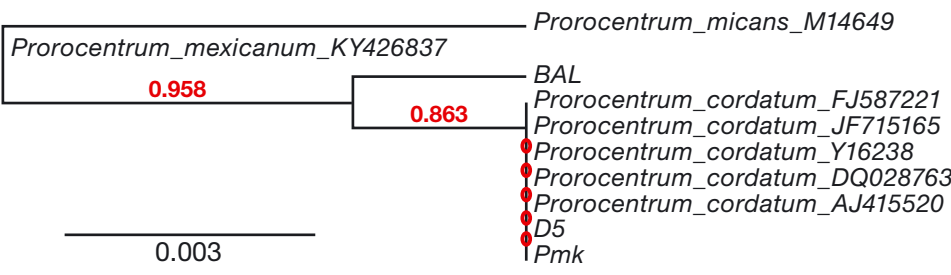

Fig. 1. Phylogenetic relationship between Prorocentrum cordatum (Ostenfeld) J. D. Dodge, 1975, strains and other Prorocentrum species based on the 18 rDNA gene sequence analysis, using $P$. micans and $P$. mexicanum as the outgroup. Numbers at branches are the percentages on the bootstrap values. The scale bar indicates 0.003 substitution per site

phylogenetic relationship between $P$. cordatum and other Prorocentrum species, $P$. micans and $P$. mexicanum were used as the outgroup. These data confirmed that the 3 strains belonged to the P. cordatum clade (Fig. 1).

\subsection{Cell morphology}

In SEM analyses, all $P$. cordatum strains appeared as oval-round cells in plate view (Fig. 2A-C). The antapical cell end was usually rounded and the apical end was truncate, with a very slight depression. An anterior spine (single tooth) was always present, and the surface of the plates was covered by minute spines. All the strains presented an apical pore region with 2 pores, a smaller circular auxiliary pore and a larger elongated flagellar pore. The pores were surrounded by small periflagellar platelets consisting of a curved apical collar, forked tooth, single tooth, ridge edge and small tooth (Fig. 2D).

\subsection{Cell dimensions and growth at 3 salinities}

The cell dimensions ranged between 10.8 and 19.1 $\mu \mathrm{m}$ in length and from 10.8 to $18.0 \mu \mathrm{m}$ in width. At all salinities, BAL was the smallest and PmK the largest (Table 1). The ANOVA tests for all of the strains showed that there were significant differences between the strain lengths and widths when they were grown at the different salinities $(p<0.05)$.

Exponential growth was observed between Days 3 and 14. This interval was used for the calculation of growth rate. Overall, the specific growth rates $(\mu)$ for these 3 strains ranged from $0.173 \pm 0.023$ to $0.398 \pm$ $0.071 \mathrm{~d}^{-1}$ (Table 2). All of the strains showed their slowest growth rate at 8, and D5 and PmK had maximal growth rates at 16 . BAL showed only minimal differences of growth between the 3 salinities.

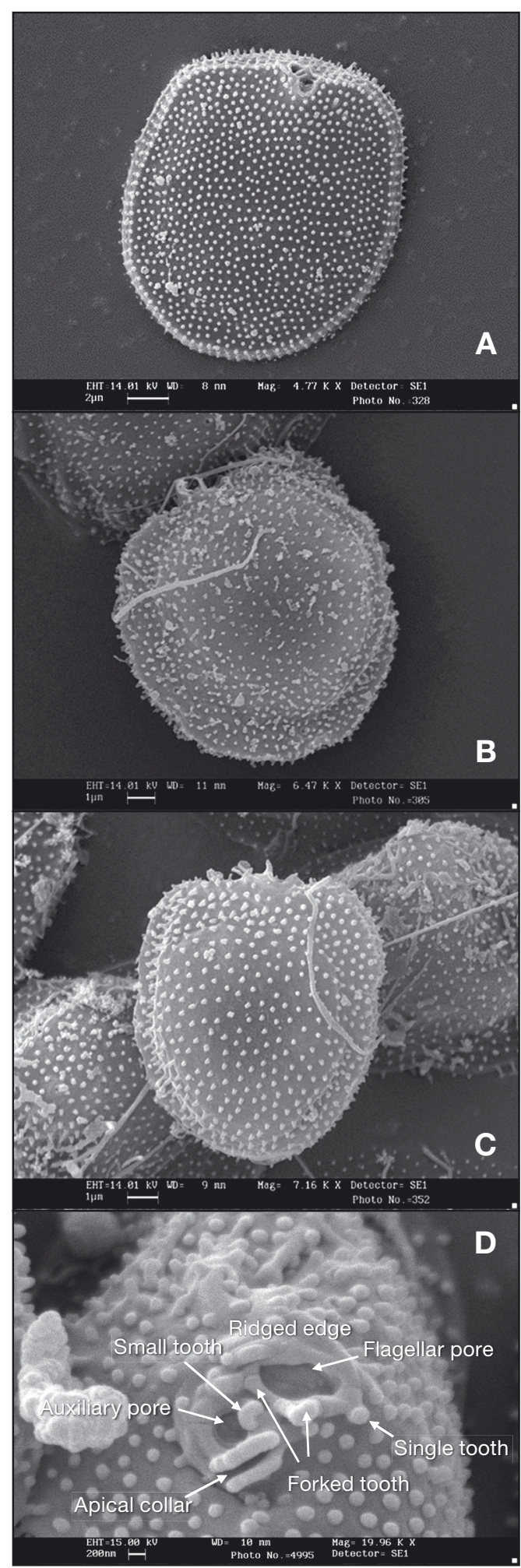

Fig. 2. Scanning electron microscope (SEM) image of Prorocentrum cordatum strains from (A) the Adriatic, (B) Chesapeake Bay and (C) the Baltic. (D) Apical pore region showing auxiliary and flagellar pores, apical collar, small tooth, ridged edge, and single and forked teeth 
Table 1. Measurements $(\mu \mathrm{m})$ of 3 Prorocentrum cordatum strains, each grown under 3 salinities, as defined using an inverted microscope. Data are means from 40 specimens for each measure for each strain at exponential phase. BAL: Baltic strain; D5: Chesapeake strain; PmK: Adriatic strain

\begin{tabular}{|c|c|c|c|c|c|c|c|c|c|c|c|c|c|c|c|c|}
\hline \multirow[b]{2}{*}{ Strain } & \multicolumn{6}{|c|}{ Salinity: $8-$} & \multirow[b]{2}{*}{ Median } & \multirow[b]{2}{*}{ Mean } & \multirow{2}{*}{$\begin{array}{r}16 \\
\mathrm{SD}\end{array}$} & \multirow[b]{2}{*}{ Min. } & \multirow[b]{2}{*}{ Max. } & \multirow[b]{2}{*}{ Median } & \multirow[b]{2}{*}{ Mean } & \multirow{2}{*}{$\begin{array}{r}-32 \\
\text { SD }\end{array}$} & \multirow[b]{2}{*}{ Min. } & \multirow[b]{2}{*}{ Max. } \\
\hline & & Median & Mean & $\mathrm{SD}$ & Min. & Max. & & & & & & & & & & \\
\hline \multirow[t]{2}{*}{ BAL } & Length & 13.7 & 13.3 & 1.179 & 10.8 & 14.4 & 13.7 & 13.3 & 1.733 & 10.8 & 17.3 & 14.2 & 14.0 & 1.348 & 11.5 & 17.3 \\
\hline & Width & 13.0 & 12.9 & 1.205 & 10.8 & 14.4 & 12.6 & 12.4 & 1.369 & 10.8 & 15.5 & 14.1 & 13.8 & 1.266 & 11.5 & 16.6 \\
\hline \multirow[t]{2}{*}{ D5 } & Length & 15.1 & 15.0 & 1.540 & 11.5 & 18.0 & 14.4 & 14.3 & 1.768 & 10.8 & 16.2 & 14.4 & 14.2 & 1.832 & 10.8 & 18.0 \\
\hline & Width & 14.4 & 14.0 & 1.018 & 11.5 & 16.2 & 13.7 & 13.4 & 1.438 & 10.8 & 16.2 & 13.9 & 13.3 & 1.665 & 10.8 & 16.9 \\
\hline \multirow[t]{2}{*}{ PmK } & Length & 17.6 & 17.2 & 1.186 & 14.4 & 19.1 & 17.3 & 16.9 & 1.935 & 12.6 & 18.0 & 18.0 & 17.1 & 1.505 & 14.4 & 18.7 \\
\hline & Width & 16.2 & 15.7 & 1.680 & 10.8 & 18.0 & 15.5 & 15.7 & 1.801 & 12.6 & 18.0 & 16.2 & 16.0 & 1.612 & 12.6 & 18.0 \\
\hline
\end{tabular}

Table 2. Growth rates $(\mu)$ of 3 Prorocentrum cordatum strains at salinities of 8,16 and 32. Data are means \pm SD. BAL: Baltic strain; D5: Chesapeake strain; PmK: Adriatic strain

\begin{tabular}{|lccc|}
\hline \multirow{2}{*}{ Strain } & \multicolumn{4}{c|}{ Growth rate $\left(\mu, \mathrm{d}^{-1}\right)$} & \multicolumn{1}{c|}{32} \\
\cline { 2 - 4 } & 8 & $0.301 \pm 0.040$ & $0.350 \pm 0.040$ \\
BAL & $0.302 \pm 0.032$ & $0.376 \pm 0.003$ & $0.361 \pm 0.058$ \\
D5 & $0.255 \pm 0.036$ & $0.398 \pm 0.071$ & $0.341 \pm 0.046$ \\
PmK & $0.173 \pm 0.023$ & 0.041 & \\
\hline
\end{tabular}

\subsection{Growth, cell volume and elemental analysis at salinity 16}

All 3 growth curves at salinity 16, measured with the Coulter counter, showed a similar trend (Fig. 3). Exponential growth was observed between Days 0 and 7 , and the maxima were reached between 200000 (PmK) and 300000 (D5 and BAL) cells ml ${ }^{-1}$ at the end of the experiment (Fig. 3).

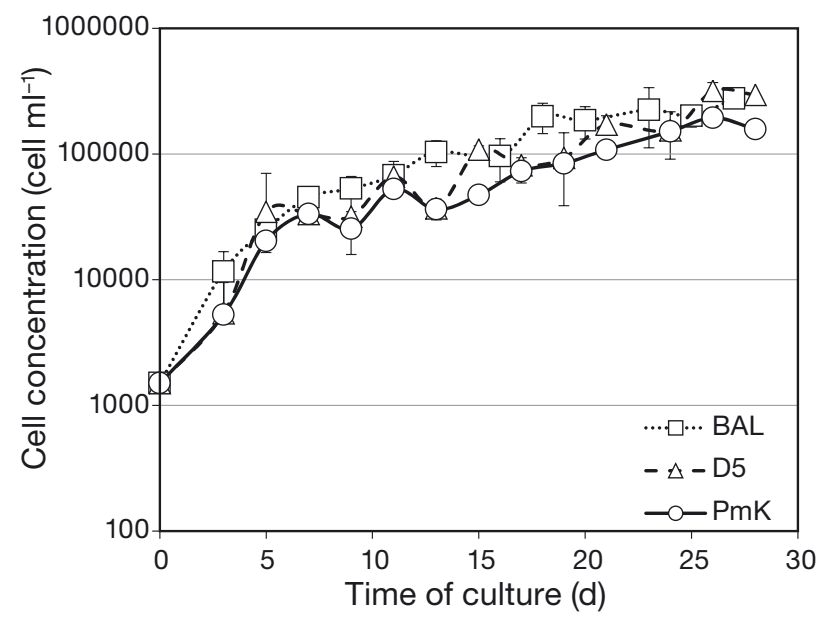

Fig. 3. Growth curves of the 3 Prorocentrum cordatum strains (Baltic [BAL], Chesapeake [D5], Adriatic [PmK]) at salinity 16. Data are means $\pm \mathrm{SD}$
The strain PmK always had the highest cell volume and D5 always the lowest (Fig. 4A). Cell volumes changed over time during the growth curves. For D5 and PmK, cell volumes decreased until Day 7 and then increased to Day 20. Similarly, the BAL cell volume decreased to Day 9 and then increased until the
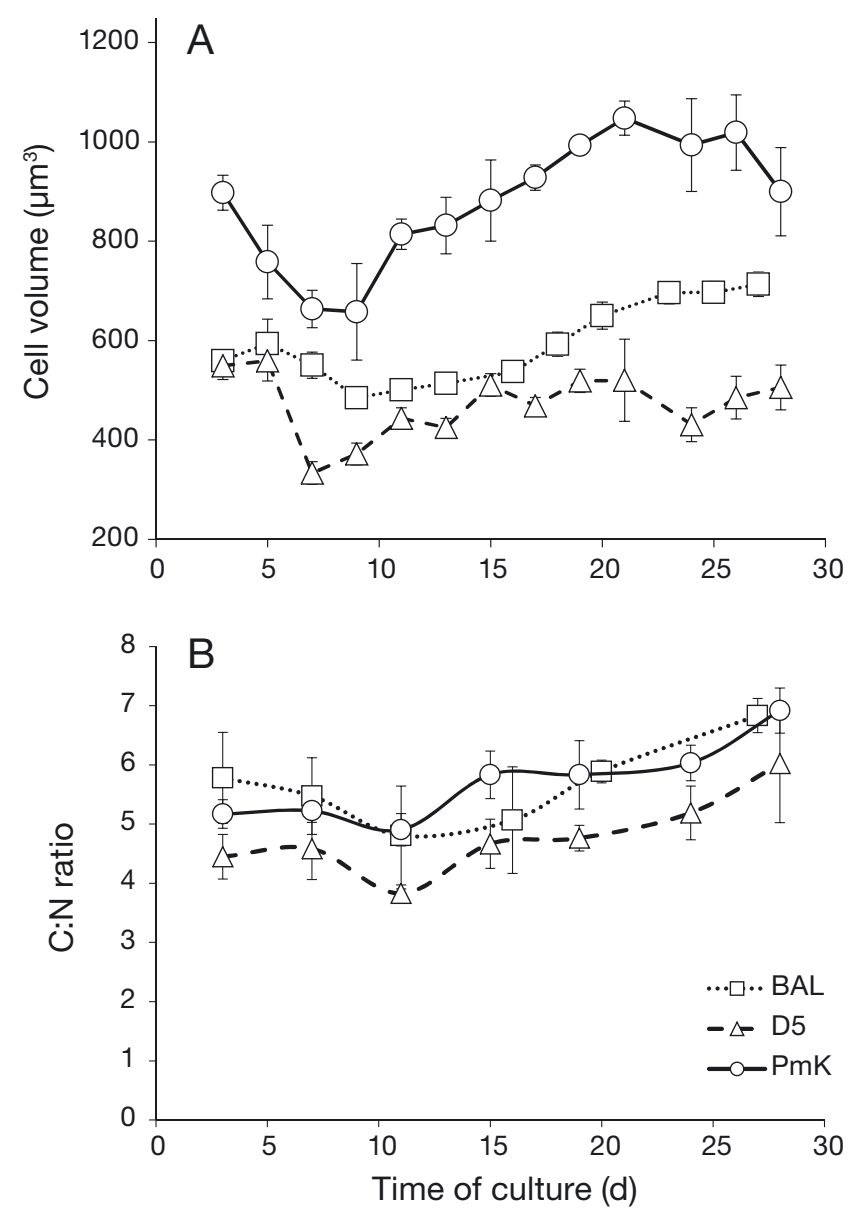

Fig. 4. (A) Cell volumes of the 3 Prorocentrum cordatum strains at different times; (B) C:N ratios of the $3 P$. cordatum strains (Baltic [BAL], Chesapeake [D5], Adriatic [PmK]) at salinity 16. Data are means $\pm \mathrm{SD}$ 
end of the experiment (Day 27). The mean cell volumes of the 3 strains were significantly different from each other $(\mathrm{p}<0.05)$.

For all the strains, the $\mathrm{C}: \mathrm{N}$ ratio increased with the age of these cultures, although they all showed a small decrease around Day 11 (Fig. 4B). D5 had the lowest C:N ratio, which was significantly different from the other 2 strains $(p<0.05)$, whereas the BAL and PmK values were not significantly different from each other $(p>0.05)$. Overall, $C: N$ ratios ranged from 3.8 to 6.9 .

The strains showed different temporal patterns with the POC measured as carbon per cell. For BAL, POC decreased from $173 \pm 23 \mathrm{pg} \mathrm{cell}^{-1}$ at the beginning to $137 \pm 6 \mathrm{pg} \mathrm{cell}^{-1}$ at the end of the growth curves (i.e. Day 27). Similarly, POC decreased in D5 from $353 \pm 15$ to $157 \pm 21 \mathrm{pg} \mathrm{cell}^{-1}$ and in PmK from $650 \pm 160$ to $277 \pm 15 \mathrm{pg} \mathrm{cell}^{-1}$. At the end of the growth curve, there was a decrease in POC per cell in all the strains. The cellular nitrogen content (i.e. PN per cell) showed similar temporal patterns as $\mathrm{POC}$, ranging from $127 \pm$ 35 to $20 \pm 0.5$ pg cell $^{-1}$ by Day 27 or 28 .

From the comparison between the cell volume and POC per cell (Fig. 5), the 3 strains were easily distinguished. PmK had the greatest cell volume and POC per cell, while D5 had the smallest cell volume and intermediate POC per cell. BAL, therefore, had intermediate cell volume and the smallest POC per cell on average. These differences revealed that for PmK

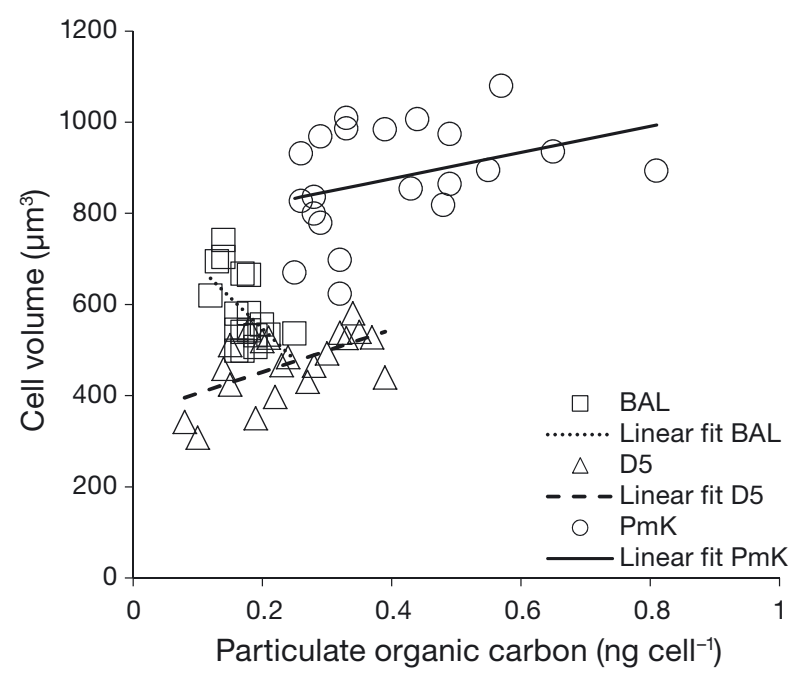

Fig. 5. Relationship between particulate organic carbon per cell and cell volume of Prorocentrum cordatum. Data were pooled for each strain: Baltic (BAL), Chesapeake (D5) and Adriatic (PmK). The results of linear regression with intercept $A$, slope $B$ and Pearson correlation coefficient $R$ are BAL: $\mathrm{A}=822.4 \pm 91.0, \mathrm{~B}=-1377.3 \pm 520.5, \mathrm{R}=-0.55$; $\mathrm{D} 5: \mathrm{A}=$ $358.2 \pm 39.5, \mathrm{~B}=467.4 \pm 154.5, \mathrm{R}=0.57$; and PmK: $\mathrm{A}=761 \pm$ $74.1, \mathrm{~B}=287.8 \pm 172.1, \mathrm{R}=0.35$ and D5, the cell volume was positively correlated to the POC per cell, while for BAL, this correlation was negative.

\subsection{Delayed fluorescence and in vivo fluorescence}

DFI, calculated from the 1st second of the measurement, showed a similar trend of growth in all 3 strains (Fig. 6A). After a rapid growth during the first week, it did not increase in the next few days. Afterwards, it grew slowly until Day 21. After Day 26, a senescence was indicated in PmK and D5. In BAL, the decay was not yet observed at the end of the curve. The DFI growth curves differed significantly between the strains $(\mathrm{p}<0.05)$.

In vivo fluorescence (Fig. 6B) had a different trend of growth than DFI. It was increasing until Day 11 in
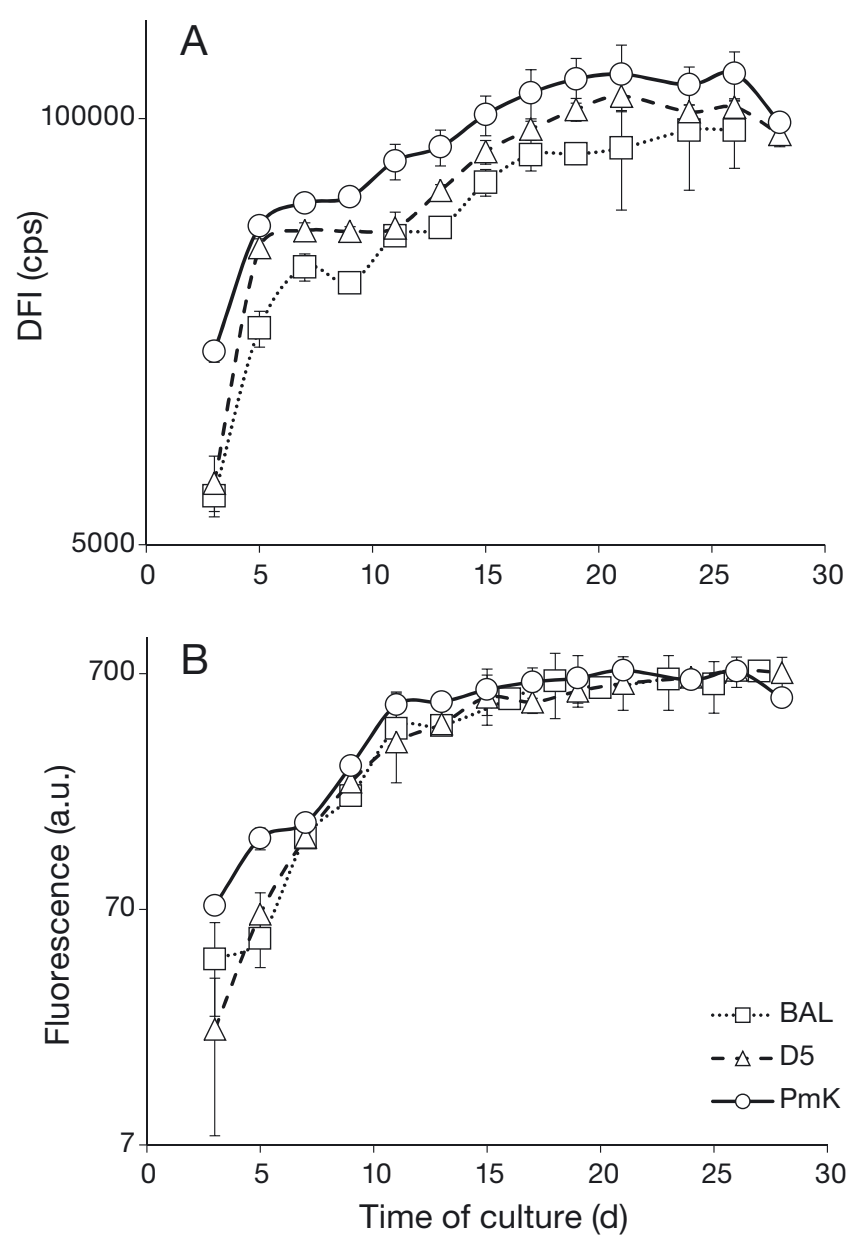

Fig. 6. (A) Delayed fluorescence intensity (DFI) and (B) in vivo fluorescence of the 3 Prorocentrum cordatum strains (Baltic [BAL], Chesapeake [D5], Adriatic [PmK]) during culture growth at salinity 16 . Data are means \pm SD. cps: counts per second; a.u.: arbitrary units 
PmK and BAL and until Day 15 in D5. Afterwards, however, it was more or less constant. Overall, the in vivo fluorescence growth curves differed significantly only between BAL and PmK ( $p<0.05)$.

To compare DFI and fluorescence ( $F \mathrm{~m})$ with culture density, the ratios were calculated from the intervals of the DFI and fluorescence exponential growth. Only the data in the interval of the DFI and fluorescence increase were included in the analysis: the DFI values were fitted from about 11000 to 70000,11000 to 80000 and 11000 to 200000 cells ml ${ }^{-1}$ in PmK, D5 and BAL, respectively; the in vivo fluorescence values were fitted from the beginning of the experiment until about 40000 cells ml $^{-1}$ in PmK and D5 and until 80000 cells ml $\mathrm{m}^{-1}$ in BAL. Table 3 gives the data for the mean ratios for both DFI cell ${ }^{-1}$ and $\mathrm{Fm} \mathrm{cell}^{-1}$; these differed significantly between 3 strains ( $p<0.05$ ), with PmK having the highest and BAL the lowest ratios. High DFI per cell and Fm per cell ratios go along with high cell volume and POC per cell.

\subsection{Delayed fluorescence decay kinetics}

DF decay kinetics varied during the growth of all 3 of the strains. The peak for BAL showed the least delay at the beginning of growth, with more delay starting from Day 13. BAL then became the most delayed of all of the strains in the period from Days 16 to 21 (Fig. 7A). Peak positions for D5 and PmK showed the same trends of change with culture growth, although the PmK peak was more delayed for most of the growth period (Fig. 7A). Peak intensity, on the other hand, changed similarly for all 3 strains (Fig. 7B); it was higher in the first few days, then declined to Day 9 (Day 11 for D5) and then increased to Day 19 for D5 and PmK and to Day 27 for BAL. Overall, there were no significant differences between the strains (Fig. 7B). The later increase in BAL peak intensity toward the end might result from the slower growth for BAL under these laboratory conditions.

Table 3. Mean ratios of delayed fluorescence intensity (DFI) per cell and fluorescence (Fm) per cell of 3 Prorocentrum cordatum strains. Data are means \pm SD. BAL: Baltic strain; D5: Chesapeake strain; PmK: Adriatic strain

\begin{tabular}{|lcc|}
\hline Strain & DFI cell & Fm cell \\
\hline BAL & $0.56 \pm 0.19$ & $0.004 \pm 0.001$ \\
D5 & $1.05 \pm 0.40$ & $0.005 \pm 0.003$ \\
PmK & $2.09 \pm 0.89$ & $0.010 \pm 0.004$ \\
\hline
\end{tabular}
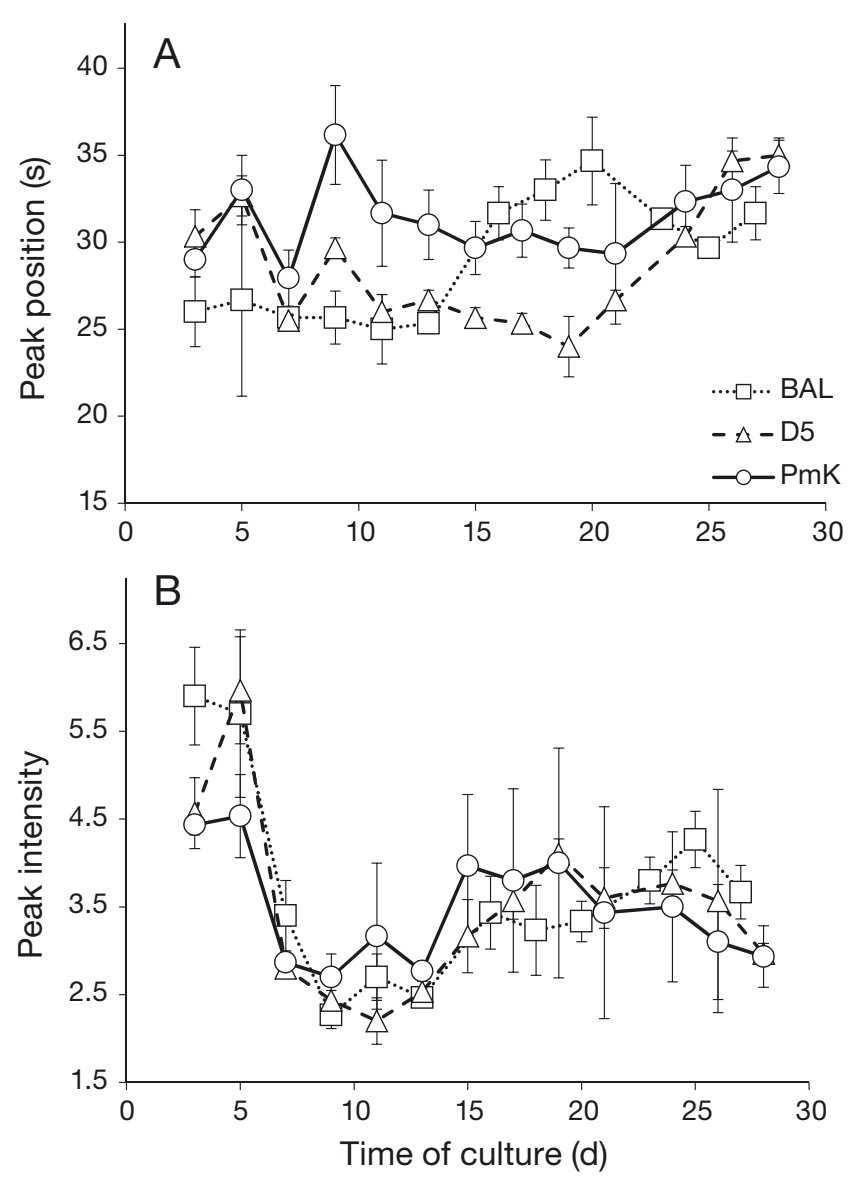

Fig. 7. Delayed fluorescence decay kinetics of the 3 Prorocentrum cordatum strains: Baltic (BAL), Chesapeake (D5) and Adriatic (PmK). (A) Peak position (expressed as seconds after the beginning of the delayed fluorescence measurement) and (B) peak intensity (expressed as a function of culture time)

\section{DISCUSSION}

Although the strains had different specific growth rates with respect to the salinity, this study indicates that salinity was not the main driving factor for size and physiological differences between them.

Phylogenetic analyses indicated that the strains studied belong to the same species. This was reinforced by the SEM analyses, where the strains showed the ornamentation of the theca typical of the species (Monti et al. 2010).

The 3 strains differed in cell dimensions. At all studied salinities, BAL was the smallest, D5 intermediate and PmK the largest. These data suggest that dimensions do not depend directly on salinity. Although possible correlation between the dimensions and salinity for this species has been reported in some studies (Velikova \& Larsen 1999, Hajdu et al. 2000, Pertola et al. 2003, Olenina et al. 2016), no clear 
relation has been found yet. Pertola et al. (2003) reported that the smallest Baltic Prorocentrum cordatum cells were seen at the highest salinity (i.e. 12). This corresponds to the occurrence of larger $P$. cordatum near the Lithuanian coast at the lowest salinity (i.e. 0-7) (Hajdu et al. 2000) but is in contrast with findings of Velikova \& Larsen (1999), who reported larger $P$. cordatum cells in Bulgarian Black Sea waters at higher water salinities than in Romanian Black Sea and Caspian Sea waters, where the salinity was lower because of river inflow. Recently, Olenina et al. (2016) reported that cell size was inversely correlated to salinity in a P. cordatum strain from the Kalmar Algae Collection (Sweden) that was maintained at different salinities.

Specific growth rates $\left(0.17-0.40 \mathrm{~d}^{-1}\right)$ are in agreement with the laboratory study reported in a review by Heil et al. (2005). Overall low growth rate probably resulted from the PAR value utilized in the experiments, as the association between high growth rates and high light conditions seems clear for this species (Heil et al. 2005). In general, the strains had minimum growth rates at salinity 8 and maximum at 16 . BAL growth rates were similar at all salinities, which confirms its distinctive response to salinity variations. The different behaviour of BAL might be linked to its adaptiveness to frequent freshwater inputs with resulting high variability of salinity in its original environment.

Several authors (e.g. Grzebyk \& Berland 1996, Hajdu et al. 2000) reported a preference of $P$. cordatum for intermediate salinity. This preference was also confirmed in the present study. Consequently, extended comparison of strains was performed at intermediate salinity 16 . The measurements of cell volumes at salinity 16 using the Coulter principle showed changes during culture growth for all of the strains. Cell volume first decreased, probably because of the rapid successive cell division, then, after Day 7 , the volume started to increase. The C:N ratio showed a similar trend, possibly because carbon was used to increase cell size, especially the theca. After Day 7 , the lowering growth rate suggests a possible limitation in light or nutrients. The Coulter counter analysis provides a 3-dimensional measure to determine the volume, including cell thickness. In contrast, light microscopy observations will only evaluate 2 cell dimensions, overlooking the cell thickness, which changes during growth in accordance with the cell division process (Monti et al. 2010). These changes were also found in this study, as the BAL strain had lower length and width dimensions but higher volume compared to D5.
Carbon content per cell was the lowest for BAL and the highest for PmK. These data are in agreement with the data from other studies. Coats \& Harding (1988) analysed ultrastructural and physiological responses of $P$. cordatum at different light intensities and reported that at high light intensity (i.e. $238.3 \mu \mathrm{mol} \mathrm{m}{ }^{-2} \mathrm{~s}^{-1}$ ), carbon per cell was $148 \mathrm{pg} \mathrm{cell}^{-1}$, while at lower light intensity (i.e. $31.2 \mu \mathrm{mol} \mathrm{m}^{-2} \mathrm{~s}^{-1}$ ), carbon per cell was higher, at $240 \mathrm{pg} \mathrm{cell}^{-1}$. Moal et al. (1987) reported a reduction in carbon, nitrogen and protein densities of more than $50 \%$ after the shift from exponential to stationary phase. They stated that the observed reduction could be due to physiological changes induced by limiting factors in the batch cultures. In the present study, the carbon and nitrogen contents per cell decreased at the end of growth, when cells were passing into the stationary phase.

Direct comparisons of carbon contents and cell volumes clearly divided the 3 strains. There was a positive correlation for PmK and D5 and a negative correlation for BAL. This is likely to be linked to the thinner theca or larger vacuoles in BAL.

$\mathrm{C}: \mathrm{N}$ ratio has been suggested as a means to identify nutrient storage in natural populations of phytoplankton (Donaghay et al. 1978, Sakshaug 1980). The C:N ratios in the present study varied from 3.8 to 6.9. These ratios resemble those for other dinoflagellates (Strickland et al. 1969, Cullen \& Horrigan 1981, Heaney \& Eppley 1981, Taguchi 1981, Cullen et al. 1982) but are lower than those reported for P. cordatum. In particular, Paasche et al. (1984) studied the effects of nitrogen source and light-dark cycles on C:N composition. The atomic C:N ratios for $P$. cordatum were 7.84 to 10.26 under the different light regimes, similar to those reported by Coats \& Harding (1988) at 2 different light intensities (31.2 and $238.3 \mu \mathrm{mol} \mathrm{m}{ }^{-2}$ $\mathrm{s}^{-1}$ ), with C:N ratios of 6.40 and 11.1 , respectively.

In our previous studies, we established that $P$. cordatum strains exhibit different in vivo and DF characteristics when growing at their original salinities (Monti et al. 2005, Berden-Zrimec et al. 2008a). Delayed and in vivo fluorescence contain information about the fundamental processes of the photosynthetic apparatus (Goltsev et al. 2003). If the main driver for the photosynthetic differences between these strains would be salinity, greater similarities in DFI and DF kinetics would be expected when these strains were growing under the same conditions of salinity. Nevertheless, DFI showed significant difference between the growth curves of 3 strains growing at salinity 16. DFI was the lowest in BAL and the highest in PmK, the same as when they are growing at their original salinities (Monti et al. 2005). 
In vivo fluorescence was significantly different only between BAL and PmK, while DFI per cell and in vivo fluorescence per cell were significantly different between the strains. DFI per cell in the PmK cultures was probably the highest because of the largest cell volume. Also, in vivo fluorescence per cell was highest in PmK, resulting from its highest chl a cell content (Monti et al. 2005).

Because of its sensitivity to differences in the physiology of the photosynthetic electron chain, DF decay kinetics varies between algal species and even between strains (Berden-Zrimec et al. 2007, 2008b). It also reflects their physiological state (Zrimec et al. 2005, Berden-Zrimec et al. 2008b). The DF components that decay more rapidly provide information about the rate of energy absorbed by the photosynthetic membranes (Desai et al. 1983). The presence of a peak in DF decay curves shows the involvement of Photosystem I in the generation of DF at later stages (several seconds after the illumination pulse) (Desai et al. 1983, Hideg et al. 1991, Monti et al. 2005, BerdenZrimec et al. 2008b). The components that decay more slowly reflect the differences in the rates of back reactions in the electron chains and provide information on the temporary energy storage during photosynthetic electron transport (Desai et al. 1983). DF decay kinetics for the studied P. cordatum strains, evaluated according to peak position and intensity, depended both on strain and culture age. While peak intensity changed similarly for all 3 strains, peak position changed differently for BAL. The differences among the 3 strains coincided with the differences between the strains when growing at their original salinities (Monti et al. 2005), which indicates that salinity was not the main cause for the variability among the strains.

\section{CONCLUSIONS}

The Prorocentrum cordatum strains considered in the present study belong to the same species, but they show different cell dimensions, physiological responses and photosynthetic activities under the same salinity culture conditions. Salinity was not the main driving factor for the different size and photosynthetic activity across these $P$. cordatum strains. In contrast, growth of these strains was influenced by salinity. All strains showed lower specific growth rates at salinity 8 , and the intermediate salinity (16) appears to be optimal also for strains that usually live at different salinities.

Our data suggest that impending climate change, potentially increasing water run-off from the land and subsequently changing the salinity of coastal waters, would not influence the dimensions and photosynthetic activity of $P$. cordatum but might nonetheless influence growth and cell concentrations, with consequent effects on bloom events.

Acknowledgements. This study was financed by Slovenian Research Agency grant P1-0237. Part of this study was funded by the European Union and Friuli-Venezia Giulia region INTERREG/ECOMADR project and by an EU ARI Programme. The authors thank T. Diociaiuti for graphic support.

\section{LITERATURE CITED}

Altschul SF, Madden TL, Schaffer AA, Zhang J, Zhang Z, Miller W, Lipman DJ (1997) Gapped BLAST and PSIBLAST: a new generation of protein database search programs. Nucleic Acids Res 25:3389-3402

Azanza RV, Fukuyo Y, Yap LG, Takayama H (2005) Prorocentrum minimum bloom and its possible link to a massive fish kill in Bolinao, Pangasinan, northern Philippines. Harmful Algae 4:519-524

Berden-Zrimec M, Drinovec L, Zrimec A, Tišler T (2007) Delayed fluorescence in algal growth inhibition tests. Cent Eur J Biol 2:169-181

* Berden-Zrimec M, Flander-Putrle V, Drinovec L, Zrimec A, Monti M (2008a) Growth, delayed fluorescence and pigment composition of four Prorocentrum minimum strains growing at two salinities. Biol Res 41:11-23

Berden-Zrimec M, Drinovec L, Molinari I, Zrimec A, Fonda Umani S, Monti M (2008b) Delayed fluorescence as a measure of nutrient limitation in Dunaliella tertiolecta. J Photochem Photobiol B 92:13-18

Bursa A (1959) The genus Prorocentrum Ehrenberg. Morphodynamics, protoplasmatic structures and taxonomy. Can J Bot 37:1-31

Cabrini M, Fornasaro D, Cossarini G, Lipizer M, Virgilio D (2012) Phytoplankton temporal changes in a coastal northern Adriatic site during the last 25 years. Estuar Coast Shelf Sci 115:113-124

* Caroppo C, Pagliara P, Azzaro F, Miserocchi S, Azzaro M (2017) Late summer phytoplankton blooms in the changing polar environment of the Kongsfjorden (Svalbard, Arctic). Cryptogam, Algol 38:53-72

Coats DW, Harding LW Jr (1988) Effect of light history on the ultrastructure and physiology of Prorocentrum marie-lebourie (Dinophyceae). J Phycol 24:67-77

Cullen JJ, Horrigan SG (1981) Effects of nitrate on the diurnal vertical migration, carbon to nitrogen ratio, and the photosynthetic capacity of the dinoflagellate Gymnodinium splendens. Mar Biol 62:81-89

Cullen JJ, Horrigan SG, Huntley ME, Reid FMH (1982) Yellow water in La Jolla Bay, California, July 1980. I. A bloom of the dinoflagellate, Gymnodinium flavum Kofoid and Swezy. J Exp Mar Biol Ecol 63:67-80

* Desai TS, Rane SS, Tatake VG, Sane PV (1983) Identification of far-red-induced relative increase in the decay of delayed light emission from photosynthetic membranes with thermoluminescence peak $\mathrm{V}$ appearing at $321 \mathrm{~K}$. Biochim Biophys Acta 724:485-489

Dodge JD (1975) The Prorocentrales (Dinophyceae). II. Revi- 
sion of the taxonomy within the genus Prorocentrum. Bot J Linn Soc 71:103-125

Donaghay PL, DeManche JM, Small LF (1978) On predicting phytoplankton growth rates from carbon:nitrogen ratio. Limnol Oceanogr 23:359-362

Fan C, Glibert PM, Burkholder JA (2003) Characterization of the affinity for nitrogen, uptake kinetics, and environmental relationships for Prorocentrum minimum in natural blooms and laboratory cultures. Harmful Algae 2: 283-299

Fonda Umani S (1985) Hydrology and 'red tides' in the Gulf of Trieste (North Adriatic). Oebalia 11 NS:141-147

Fukuyo Y, Takano H, Chihara M, Matsuoka K (eds) (1990). Red tide organisms in Japan: an illustrated taxonomic guide. Uchida Rokakuho, Tokyo, p 30-31

Glibert PM, Magnien R, Lomas MW, Alexander J and others (2001) Harmful algal blooms in the Chesapeake and coastal bays of Maryland, USA: comparison of 1997, 1998, and 1999 events. Estuaries 24:875-883

Glibert PM, Allen JI, Artioli Y, Beusen A and others (2014) Vulnerability of coastal ecosystems to changes in harmful algal bloom distribution in response to climate change: projections based on model analysis. Glob Chang Biol 20:3845-3858

Goltsev V, Zaharieva I, Lambrev P, Yordanov I, Strasser R (2003) Simultaneous analysis of prompt and delayed chlorophyll a fluorescence in leaves during the induction period of dark to light adaptation. J Theor Biol 225: 171-183

Grzebyk D, Berland B (1996) Influence of temperature, salinity and irradiance on growth of Prorocentrum minimum (Dinophyceae) from the Mediterranean Sea. J Plankton Res 18:1837-1849

Grzebyk D, Denardou A, Berland B, Pouchus Y (1997) Evidence of a new toxin in the red-tide dinoflagellate Prorocentrum minimum. J Plankton Res 19:1111-1124

Guillard RRL (1975) Culture of phytoplankton for feeding marine invertebrates. In: Smith WL, Chanley MH (eds) Culture of marine invertebrate animals. Plenum Press, New York, NY, p 29-60

* Guiry MD, Guiry GM (2017). AlgaeBase. World-wide electronic publication, National University of Ireland, Galway. www.algaebase.org (accessed on 12 October 2017)

Hajdu S, Edler L, Olenina I, Witek B (2000) Spreading and establishment of the potentially toxic dinoflagellate Prorocentrum minimum in the Baltic Sea. Int Rev Hydrobiol 85:561-575

Harding LW Jr, Coats DW (1988) Photosynthetic physiology of Prorocentrum marie-lebouriae (Dinophyceae) during its subpycnocline transport in Chesapeake Bay. J Phycol 24:77-89

Heaney SI, Eppley RW (1981) Light, temperature and nitrogen as interacting factors affecting diel vertical migrations in dinoflagellates in culture. J Plankton Res 3:331-344

*Hedges JI, Stern JH (1984) Carbon and nitrogen determinations of carbonate-containing solids. Limnol Oceanogr 29:657-663

Heil CA, Glibert PM, Fan C (2005) Prorocentrum minimum (Pavillard) Schiller: a review of a harmful algal bloom species of growing worldwide importance. Harmful Algae 4:449-470

HELCOM (Helsinki Commission) (1996) Third periodic assessment of the state of the marine environment of the Baltic Sea, 1989-1993; background document. Balt Sea Environ Proc No. 64 B, HELCOM, Helsinki
Hideg E, Kobayashi M, Inaba H (1991) The far red induced slow component of delayed light from chloroplasts emitted from photosystem II. Evidence from emission spectroscopy. Photosynth Res 29:107-112

*Hoppenrath M (ed) (2017) Prorocentrales. In: Moestrup Ø, Akselmann R, Fraga S, Hoppenrath $\mathrm{M}$ and others (eds) IOC-UNESCO Taxonomic Reference List of Harmful Micro Algae. www.marinespecies.org/hab (accessed on 12 October 2017)

Jensen MØ, Moestrup Ø (1997) Autoecology of the toxic dinoflagellate Alexandrium ostenfeldii: life history and growth at different temperatures and salinities. Eur J Phycol 32:9-18

Krakhmalny AF, Tishaeva MV, Panina ZA, Krakhmalny MA (2004) A problem on identity Prorocentrum cordatum (Ostf.) Dodge and P. minimum (Pavill.) Schiller (Dinophyta). Int J Algae 6:331-340

Laabir M, Jauzein C, Genovesi B, Masseret E and others (2011) Influence of temperature, salinity and irradiance on the growth and cell yield of the harmful red tide dinoflagellate Alexandrium catenella colonizing Mediterranean waters. J Plankton Res 33:1550-1563

MacIntyre HI, Cullen JJ (2005) Using cultures to investigate the physiological ecology of microalgae. In: Andersen RA (ed) Algal culturing techniques. Elsevier Academic Press, Amsterdam, p 287-326

Marasović I (1986) Occurrence of Prorocentrum minimum in the Adriatic Sea. Rapp P-V Réun Comm Int Explor Sci Mer Méditer 30:186

* Marasović I (1989) Encystment and excystment of Gonyaulax polyedra during a red tide. Estuar Coast Shelf Sci 28: $35-41$

Marasović I, Pucher-Petković T, Alegria V (1988) Relation between phytoplankton productivity and Sardina pilchardus in the middle Adriatic. FAO Fish Rep 394: 41-50

Marasović I, Pucher-Petković T, Petrova-Karadjova V (1990) Prorocentrum minimum (Dinophyceae) in the Adriatic and Black seas. J Mar Biol Assoc UK 70:473-476

Martin GW (1929) Dinoflagellates from marine and brackish waters of New Jersey. Univ Iowa Stud Nat Hist 12:56-58

* Maxwell K, Johnson GN (2000) Chlorophyll fluorescencea practical guide. J Exp Bot 51:659-668

Mendez SM (1993) Uruguayan red tide monitoring programme: preliminary results (1990-1991). In: Smayda TJ, Shimizu Y (eds) Toxic phytoplankton blooms in the sea. Elsevier, Amsterdam, p 287-291

Moal J, Martin Jezequel V, Harris RP, Semain JF, Poulet SA (1987) Interspecific and intraspecific variability of the chemical composition of marine phytoplankton. Oceanol Acta 10:339-346

Moncheva D, Petrova-Kardjova V, Palasov A (1995) Harmful algal blooms along the Bulgarian Sea coast and possible patterns of fish and zoobenthos mortalities. In: Lassus $P_{\text {, }}$ Arzul G, Erard-Le Denn E, Gentien P, Marcaillou-Le Baut C (eds) Harmful marine algal blooms. Lavoisier, Paris, p 193-198

Monti M, Zrimec A, Beran A, Berden Zrimec M, Drinovec L, Kosi G, Tamberlich F (2005) Delayed luminescence of Prorocentrum minimum under controlled conditions. Harmful Algae 4:643-650

Monti M, Stoecker DS, Cataletto B, Talarico L (2010) Morphology of the flagellar pore complex in Prorocentrum minimum (Dinophyceae) from the Adriatic and Baltic seas. Bot Mar 53:357-365 
Montresor M, John U, Beran A, Medlin LK (2004) Alexandrium tamutum sp. nov. (Dinophyceae): a new nontoxic species in the genus Alexandrium. J Phycol 40:398-411

Olenina I, Vaičiukynas E, Šulčius S, Paškauskas R and others (2016) The dinoflagellate Prorocentrum cordatum at the edge of the salinity tolerance: the growth is slower but cells are larger. Estuar Coast Shelf Sci 168:71-79

Paasche E, Bryceson I, Tangen K (1984) Interspecific variation in dark nitrogen uptake by dinoflagellates. J Phycol 20:394-401

Parke M, Ballantine D (1957) A new marine dinoflagellate Exuviella marie-lebouriae n. sp. J Mar Biol Assoc UK 36: 643-650

Pertola S, Faust MA, Kuosa H, Hällfors G (2003) Morphology of Prorocentrum minimum (Dinophyceae) in the Baltic Sea and in Chesapeake Bay: comparison of cell shape and thecal ornamentation. Bot Mar 46:477-486

Pucher-Petković T, Marasović I (1987) Contribution à la connaissance d'une poussée extraordinaire d'algues unicellulaires (Adriatique Septentrionale). Centro 1:33-34

Rabbani MM, Rehman AU, Harms CE (1990) Mass mortality of fishes caused by dinoflagellate bloom in Gwadar Bay, southwestern Pakistan. In: Granéli E, Sundstrom B, Edler L, Anderson DM (eds) Toxic marine phytoplankton. Elsevier, New York, NY, p 209-214

Röder $\mathrm{K}$, Hantzsche FM, Gebühr C, Miene C and others (2012) Effects of salinity, temperature and nutrients on growth, cellular characteristics and yessotoxin production of Protoceratium reticulatum. Harmful Algae 15: 59-70

Sakshaug E (1980) Problems in the methodology of studying phytoplankton. In: Morris I (ed) The physiological ecology of phytoplankton. Blackwell, Oxford, p 57-91

Salgado P, Vázquez JA, Riobó P, Franco JM, Figueroa RI, Kremp A, Bravo I (2015) A kinetic and factorial approach to study the effects of temperature and salinity on growth and toxin production by the dinoflagellate Alexandrium ostenfeldii from the Baltic Sea. PLOS ONE 10:e0143021

Schiller J (1933) Dinoflagellatae (Peridineae). In: Kolkwitz (ed) Rabenhorst's Kryptogamen-Flora von Deutschland, Österreich und der Schweiz, 2nd edn, Section 3, Part 1. Academische Verlagsgesellschaft, Leipzig, p 1-617

Silva ES (1980) As grandes populaces de dinoflaellados toxicos ne lagoa de Obidos, Vol 4. Arquivos do Instituto Nacional de Saude, Lisbon, p 253-262

Silva ES (1985) Ecological factors related to Prorocentrum minimum blooms in Obidos Lagoon (Portugal). In: Anderson DM, White A, Baden D (eds) Toxic dinoflagellates. Elsevier, New York, NY, p 251-256

Silva ES, Sousa I (1981) Experimental work on the dinoflagellate toxin production, Vol 6. Arquivos do Instituto Nacional de Saude, Lisbon, p 381-387

Solum I (1962) The taxonomy of Dinophysis populations in Norwegian waters in view of biometric observations. Nytt Mag Bot 10:5-33

Editorial responsibility: Kedong Yin, Brisbane, Queensland, Australia
Strickland JDH, Holm-Hansen O, Eppley RW, Linn RJ (1969) The use of deep tank in plankton ecology. I. Studies of the growth and composition of phytoplankton crops at low nutrient levels. Limnol Oceanogr 14:23-34

Taguchi S (1981) Seasonal studies of the dinoflagellate Ceratium longipes (Bailey) Gran in the Bedford Basin, Canada. J Exp Mar Biol Ecol 55:115-131

Tangen K (1980) Brown water in Oslofjord, Norway, in September, caused by the toxic Prorocentrum minimum and other dinoflagellates. Blyttia 38:145-158

Taylor FJR, Fukuyo Y, Larsen J (1995) Taxonomy of harmful dinoflagellates. In: Hallegraeff GM, Anderson DM, Cembella AD (eds) Manual on harmful marine microalgae. IOC Manuals and Guides No. 33, UNESCO, Paris, p 283-317

Taylor FJR, Fukuyo Y, Larsen J, Hallegraeff GM (2003) Taxonomy of harmful dinoflagellates. In: Hallegraeff GM, Anderson DM, Cembella AD (eds) Manual on harmful marine microalgae. Monographs on Oceanographic Methodology No. 11, UNESCO, Paris, p 389-432

Tseng CK, Zhou MJ, Zou JZ (1993) Toxic phytoplankton studies in China. In: Smayda TJ, Shimizu Y (eds) Toxic phytoplankton blooms in the sea. Elsevier, New York, NY, p 347-352

* Tyler MA, Seliger HH (1978) Annual subsurface transport of a red tide dinoflagellate to its bloom area: water circulation patterns and organism distribution in the Chesapeake Bay. Limnol Oceanogr 23:227-246

Tyler MA, Seliger HH (1981) Selection for a red tide organism: physiological responses to the physical environment. Limnol Oceanogr 26:310-324

Utermöhl H (1958) Zur Vervollkommung der quantitativen Phytoplankton-Methodik. Mitt Int Ver Theor Angew Limnol 9:1-38

*Vanucci S, Pezzolesi L, Pistocchi R, Ciminiello P and others (2012) Nitrogen and phosphorus limitation effects on cell growth, biovolume, and toxin production in Ostreopsis cf. ovata. Harmful Algae 15:78-90

Velikova V, Larsen J (1999) The Prorocentrum cordatum/ Prorocentrum minimum taxonomic problem. Grana 38: 108-112

*Wasmund N, Göbel J, Bodungen BV (2008) 100-yearschanges in the phytoplankton community of Kiel Bight (Baltic Sea). J Mar Syst 73:300-322

Witek B, Pliński M (2000) The first recorded bloom of Prorocentrum minimum (Pavillard) Schiller in the coastal zone of the Gulf of Gdansk. Oceanologia 42:29-36

Wood AM, Everroad RC, Wingard LM (2005) Measuring growth rates in microalgal cultures. In: Andersen RA (ed) Algal culturing techniques. Elsevier Academic Press, Burlington, MA, p 269-285

Zrimec A, Drinovec L, Berden-Zrimec M (2005) Influence of chemical and physical factors on long-term delayed fluorescence in Dunaliella tertiolecta. Electromagn Biol Med 24:309-318

Submitted: May 10, 2017; Accepted: October 10, 2018

Proofs received from author(s): December 19, 2018 